\title{
LES MATINÉES DU ROI DE PRUSSE.
}

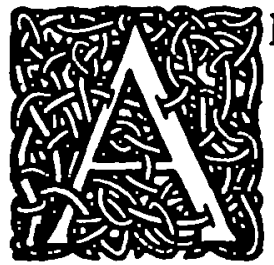

$\mathrm{N}$ old literary problem has been revived by Sir William Whittall's publication of a transcript and translation of what is known as the Smyrna MS. of the once famous work' Les Matinées du Roi de Prusse.' The existence of this manuscript, or we should perhaps say of the copy of it taken by Sir William Whittall's grandfather, had long been known from the 'Mémoires' of Marshal Savary, with whose narrative the account given in the introduction to this new edition is in substantial agreement. When the Emperor Napoleon was exiled to Elba, Savary begged leave of the French Government to accompany him. His request was not granted, and he was himself imprisoned. Escaping with difficulty, he found a temporary refuge at Smyrna, where one of the leading English merchants, Mr. Charlton Whittall, showed him great kindness. Despite all the perils he had passed through, Savary brought with him to Smyrna, concealed-so the story goes-on his own person, a manuscript which he had stolen from Frederick the Great's writingtable in the palace of Sans Souci when he was accompanying Napoleon on his visit there. Apparently, manuscripts of the 'Matinées' abounded in Frederick's old study, as M. le Baron de Méneval, 


\section{MATINÉES DU ROI DE PRUSSE. 149}

one of Napoleon's secretaries, also claimed to have purloined on the same occasion a copy, which afterwards formed the basis of the edition published in 1863 . Savary, however, seems to have known nothing of his fellow pilferer, and to have been equally ignorant of the fact that a printed edition of the 'Matinées' had been published in Paris as recently as $180 \mathrm{I}$, and that the book had been well known throughout Europe and also in the United States since 1766 or 1767 . To him the copy he had stolen at Sans Souci was the only one in existence. The revelations it offered of the real character of Frederick the Great were too startling and terrible to be given to the world, and in permitting Mr. Whittall to take a transcript he bound him by a promise (which, without any obvious inducement to do so, he also imposed upon himself) that so long as either of them lived the book should not be made public. His story was implicitly accepted by the Whittall family, Mr. Whittall, and apparently his grandson also, being firmly convinced that this manuscript thus strangely brought to Smyrna was the only authentic copy of the 'Matinées,' and that its subsequent publication was due to the treachery of a clerk who had inadvertently been allowed to see the transcript. Of the numerous editions printed in the eighteenth century neither Mr. Whittall nor Sir William seems ever to have heard, and their testimony is, perhaps, all the more to be regarded for this absence of any attempt to fit it in with other facts.

So little has been heard of the 'Matinees du Roi de Prusse' during recent years, that it may be well 
to give a few extracts from the book itself to show its real character. Before he has. written more than a few lines, the author discloses the frankly cynical attitude to which he adheres throughout: - Sachez pour toujours qu'en fait de Royaume l'on prend quand on peut, et l'on n'a jamais tort que quand on est obligé de rendre.'

This maxim strikes the keynote of the policy enforced, which has self-aggrandisement for its only aim, and disregards all moral scruples; and it is in this tone that the author discusses one subject after another, applying to each the supreme test of expediency. This is how he begins his discourse on religion:

'La Religion est abrolument nécessaire à un état, c'est une maxime qu'on serait fou de disputer; et un Roi est maladroit quand il permet que ses sujets en abusent, mais aussi un Roi n'est pas sage d'en avoir. ... Voulons-nous faire un traité avec une Puissance? si nous nous souvenons seulement que nous sommes chrétiens, tout est percu, aous serons toujours dupes. Pour la guerre, c'est un métier où le plus petit scrupule gaterait tout; en effet, quel est l'honnête homrne qui voudrait la faire, si l'on n'avait pas le droit de faire des régles qui permettent le pillage, le feu et le carnage? Je ne diz pas cependant qu'il faille afficher l'impiété, mais il faut penser selon le rang qu'on occupe. Tous les Papes qui ont eu le sens commun ont eu des systèmes de Religion propres à leur agrandissement. Et ce serait le comble de la folie, si un prince s'attachait à de petites misères qui ne sont faites que pour le peuple.'

In the third Matinée, treating of Justice, we have the following remarks:

- Ne vous laissez pas éblouir, mon clier neveu, par le mot de Justice; c'est un mot qui a différens rapports et qui peut ètre expliqué de différentes manietres. Voici le scni que je jui donne. La Justice est Pimage de Dieu, qui peut donc atteindre $i$ une si 
haute perfection? N'est-on pas meme assez raisonnable, quand on se desiste du projet insensé de la posséder entièrement?'

The same strain is continued throughout: the political doctrine which Frederick recommends to his nephew, though not so far removed from what some governments practise at the present day, has probably never been advocated with such frankness as in the following passage :

'J'entends par le mot de Politique, qu'il faut toujours chercher à duper les autres; c'est le moyen, non pas d'avoir de l'avantage, mais de se trouver au pair; car soyez sûr que tous les états du monde courent la méme carrière; or, ce principe post, ne rougissez pas de faire des alliances dans la vue d'en tirer vous seul l'avantage; ne faites point la faute grossière de ne pas les abandonner quand vous croirez qu'il y a de votre interé, et surtout continuez vivement cette maxime: que de dépouiller ses voisins, c'est leur ôter les moyens de vous nuire.'

Frederick (if we accept his authorship of this astounding pamphlet) is not a whit less reticent when he comes to speak of his own private tastes and inclinations :

' La nature m'a donné des penchans assez doux, j'aime la bonne chère, le vin, le cafe, et les liqueurs, cependant mes sujets croyent que je suis le prince le plus sobre. Quand je mange en public, mon cuisinier allemand fait le diner, je bois de la bierre, et deux ou trois coups de vin. Quand je suis dans mes petits appartemens, mon cuisinier français fait tout ce qu'il peut pour me contenter, et j'avoue que je suis un peu difficile, je suis près de mon lit, et c'est ce qui me rassure sur tout ce que je bois.'

At the end of the fourth Matinée this system of worldly wisdom is summed up:

'Je vous fais connaitre, mon cher neveu, l'homme à mes dépens; croyez qu'il est toujours livré à ses passions, que l'amourpropre fait sa glvire et que ses vertus ne sont appuyées que sur son 
intérêt. Voulez-vous passer pour héros? approchez hardiment du crime; voulez-vous passer pour sage? contrefaites-vous avec art.'

Such was the work which (to take the first dated edition of which we know) was published in 1766 in a thin octavo, bearing the imprint 'Berlin.' 'The question which we would once more discuss is, Was it authentic? Carlyle naturally rejected it with all the scorn of which he was master. Nothing less congruous to his conception of Frederick's character can well be imagined. In 1863 , on the other hand, Lord Acton reviewed the evidence for its authenticity in the "Home and Foreign Review,' of which he was then editor, and pronounced decisively in its favour, following up this pronouncement by an edition of the text from a transcript (we have always to deal with transcripts, never with originals) of the copy which Savary's rival thief, Méneval, professed to have stolen at Sans Souci in 1806 . The evidence which Lord Acton adduced may be briefly summarized as follows: On the death of $M$. Humbert de Bazile, who had been the secretary of the great Buffon, a private diary of the former was published, containing a detailed account of a journey undertaken by Buffon's son to St. Petersburg, and of his reception by Frederick the Great on his way back through Berlin. Not only was the traveller handsomely treated by the King, but he was intrusted with a manuscript which he was to submit to his father on his return to Paris. This document, concerning which Frederick was so anxious to obtain the opinion of M. de Buffon, was, according to M. Humbert, 
no other than the notorious 'Matinées.' Until the publication of $\mathbf{M}$. Humbert's memoirs, it had not been known that the younger Buffon visited Berlin on his return journey, and hostile critics had not been slow to point out how unlikely it was that Frederick should have given this youth an audience and intrusted him with such an important manuscript. But here we have the explicit testimony of Buffon's private secretary, who heard the young man tell the story, and who himself handled the manuscript immediately after its arrival from Berlin.

This was Lord Acton's chief positive argument for the authenticity of the 'Matinées'; much of the rest of his article he devoted to the contentions of Herr C. Samwer, who had endeavoured to establish their spuriousness on the ground of the disappearance of the original manuscript, and such points as that the style is inferior to the King's, the opinions contrary to those on which he acted, the mistakes in chronology and in estimating the internal condition of Prussia such as he could not have been guilty of. Though no doubt effective in the mass, most of these points are highly debatable. We must not forget that while Frederick was a very great king, he was also a very conceited and amateurish man of letters. To make a hit in literature would certainly have seemed to him quite as good an object of ambition as to win a battle, and if the whole book reads very like the production of a clever literary hack, this is very much what it would be like if Frederick himself had written it. On the other hand, we have to deal with the theory that far from being the work 
of the king, the 'Matinées' were compiled and circulated at the instigation of the French Government and by some writer in their pay with the express object of bringing Frederick and his policy into suspicion and contempt. This is the view taken by Herr Samwer, who quotes two letters written by Grimm to the Duchess Louise Dorothea of Gotha in 1765 , when the 'Matinées ' were being circulated in Paris; with the first he sends a copy of the pamphlet; in the second he says: 'Je serais tenté de croire que c'est un écrit qu'on aurait escamoté au Grand Frédéric avant qu'il ait pu y mettre de la correction, et qu'on a ensuite falsifié en le faisant parler avec une prétendue sincérité bien hors de toute vraisemblance, car la première des qualités d'un prince qui aurait ces principes serait de les cacher avec la plus profonde dissimulation, et il faudrait le supposer insensé dès qu'on le croirait auteur de ces "Matinées." Much the same position is taken up by $M$. Spoll, the editor of the I 885 edition, who observes with some truth: 'On dénonce ainsi une politique; on la recommande autrement.' But after all Grimm clearly gave it as his opinion that Frederick was the author at any rate of the first draught of the book, however much it may have been altered afterwards. Yet Samwer argues that because Grimm did not mention any private Frenchman as the author, his reticence, inspired by fear of the police, was due to his conviction that the French Government had instigated the forgery. Surely this is a far-fetched and unwarranted interpretation of Grimm's words. The 'Matinées,' according to Samwer, are the work of 
a man who knew extremely little of Prussia or of the King's person. But, as Lord Acton points out, Herr Cauer (who is also against the authenticity) says that the 'Matinées' are really of value, because the author is well-informed respecting the person of Frederick the Great. The truth is that each different critic declares himself for or against the authenticity of the 'Matinées' according to his previously formed judgment of the King's character.

The objections raised by Lord Acton in reply to Herr Samwer's theory are: (I) that the book, if inspired by the French Government, would in all probability have appeared during the Seven Years' $\mathrm{W}$ ar and not after it; (2) it would not have been circulated so clandestinely that it was difficult to get a copy; (3) Frederick would have made a public protest and complained of the forgery, whereas he remained perfectly silent; (4) Grimm himself says it is certain that the author had never been in France. But the mainstay of Lord Acton's position is the unimpeachable testimony of $\mathbf{M}$. Humbert. Buffon himself believed the work to be authentic, and if we accept M. Humbert's account as substantially correct, it is difficult to see how it could be otherwise.

It is worth while noticing that even Frenchmen, who had every motive to attribute this Machiavellian treatise to the Prussian King, especially when embittered by defeat in 1870 , are by no means unanimous on the point. M. Spoll, for instance, the latest French editor, thinks that the hand of Voltaire (to whom the work was very universally attributed soon after its appearance) can be unmis- 


\section{LES MATINÉES DU}

takably recognized in its caustic pages. He holds a very high opinion of its literary merit, speaking of it as 'ce merveilleux pamphlet,' and as quite outside the range of a mere dabbler in literature like Frederick the Great. Nevertheless, he considers that the portrait drawn of the great captain in the 'Matinées' is in the main just and accurate. Now, in view of the famous quarrel between Voltaire and Frederick, this theory of the authorship is at first sight attractive; but it appears that Voltaire was already reconciled with his former master before the 'Matinées' came into circulation. Moreover, he would scarcely have put into Frederick's mouth the words concerning himself in the fourth matinte.

This being the problem, it has seemed worth while to inquire whether an examination of the different editions can throw any light on it. ${ }^{1}$ On the supposition that Frederick was the true author, and that he was anxious to obtain the opinion of men of letters on his work, we may reasonably expect to find many variations in the text, due to the King's revision. On the supposition that the work was written in France to bring Frederick into discredit, it is not likely that the text would be altered from purely literary considerations after it had once been published. Now, to which of these suppositions do the texts of the early editions lend credibility? The British Museum possesses

1 I should like to say that the idea that some results might be obtained by comparing the different texts was suggested to me by Mr. Alfred Pollard, who has also given me material help in carrying it out. 
six different French editions of the 'Matinées, either bearing the imprint of the eighteenth century or conjecturally assigned to it, besides one of the year $180 \mathrm{I}$, five published in the last half of the nineteenth century, and several translations. After careful collation of the texts it is apparent that the earliest edition known, namely, that dated 'Berlin, 1766,' must be placed in a class by itself; its text differs considerably from that of the other editions printed in the eighteenth century. These, on the other hand, have a certain family resemblance; they obviously trace their descent from the same draught which, either in manuscript or in print, has received slight variations. The 1766 edition clearly represents a different draught, so frequent and notable are the variations. Moreover, it alone of the eighteenth century editions has six matinees, the others omitting that which deals with the army. The 180 I edition ${ }^{1}$ has seven matinées; but in the sixth again we find considerable variations; and the seventh, which treats of 'Finance,' is obviously a later addition, such as one might expect to find in a fresh issue of a book that had achieved such extraordinary vogue. This added matinée consists chiefly of a somewhat tedious 'Mémoire du Conseil,' bristling with an array of facts and figures.

When we come to the editions of the latter half of the nineteenth century, our attention is claimed

'It is curious to notice that the publisher of this 1801 edition, like Savary some years afterwards, seems to imagine that he is the first in the field, for he ignores all the editions which had pre11 ceded his. 


\section{$15^{8}$}

\section{LES MATINEES DU}

by the one dated $186_{3}$, which is based on the manuscript supposed to have been copied at Sans Souci by Méneval. On this text Lord Acton had already thrown suspicions, which are fully borne out by close examination and comparison. Prof. Ranke showed that the manuscript in the archives at Berlin, which Méneval might have copied, is not in Frederick's handwriting, does not correspond with Méneval's text, and is more complete and verisimilar. To this we may now add that the Méneval text contains marked divergencies both from the earliest edition and the other group, though it is nearer to the latter, like which it only has five matinées. What is more, the additions of new matter are comparatively copious, and the whole shows unequivocal signs of having been rewritten and polished. The French is less faulty, and the sentences are rounded off so as to lose the characteristic bluntness of the original. On the whole, it must either represent the latest of several versions, or, as is more probable, have been extensively ' edited.'

The Franco-Prussian War naturally called forth a new crop of reprints in Paris, which, no doubt, appeared for the express purpose of annoying Bismarck and his countrymen. These do not follow the earliest edition, but rather the slightly fuller text of the later group. But the portrait drawn by Frederick of himself, coarse and unflattering though it was, did not appear sufficiently repellent to the patriotic French editor of the 1871 edition, who, besides other little alterations, proceeded to discover an entirely new matinée labelled 'Des 
Mœurs et de la Galanterie'; this figured as the sixth, although in all previous editions the sixth had for its subject 'Le Militaire.' It will not surprise anyone to learn that this newly-discovered Matinée turned out to be the most shamelessly cynical and revolting of the lot. But such a palpable forgery need not detain us.

So far, the comparison of the various texts has gone to support the genuineness of the work; for the variations are frequent and considerable, suggesting successive revisions of a kind which a forger would not be likely to attempt. It only remains for us to extend our examination to the new edition based on Savary's manuscript, and to see if it can be classed with any of the others. Half an hour's work will convince the most sceptical that it agrees very closely throughout with the 1766 edition, which has hitherto stood alone in a class by itself. Even such discrepancies as there are may, with tolerable certainty, be ascribed to the carelessness of a copyist. For an example we may take the sentence in the first Matinee: 'Quand aux filles, elles puisent du privilege à la mode,' where 'puisent' is merely a misreading of the 'jouissent' found in the edition of 1766 . The similarity of the two texts becomes the more striking when it is seen to extend even to obvious mistakes : e.g., at the end of the section 'Origine de notre Maison,' we have the following sentence: 'Je vois bien, mon cher neveu, que je vous laisse dans l'obscurité sur notre origine, l'on pretend que ce Comte de Zohem-zollern était d'une grand maison, mais, dans le vrai, personne ne s'est pourvû.' 
In both editions this sentence ends in the same abrupt and unintelligible manner. The last words give no sense as they stand, and Sir William Whittall is reduced to translating them: 'But to speak the truth, nobody knows.' One of the undated eighteenth century texts supplies the lacuna with the words: 'Avec moins de terres.' Another offers the variant: ' Personne n'a paru dans le monde avec moins de titres.' The 'Méneval' edition reads: 'Personne ne s'est poussé avec moins de titres.'

Here it is obvious that the original draught was defective, that the texts of what we may call Group B. have corrected it with or without authority, while our two A texts, that is the 1766 edition and Mr. Whittall's, reproduce it as it stood. When we add that Mr. Whittall's manuscript agrees with the 1766 edition in containing the sixth Matinée, and in substantially the same form, the close connection between these two texts is placed beyond dispute.

An examination of the opening passage as it stands in Mr. Whittall's version, in the edition of 1766 , and in what appears to be the earliest of the $B$ texts, ${ }^{1}$ may enable us to take yet a further step.

- This is a sexto-decimo, without date or imprint. The titlepage bears merely the words 'Matintes Royales,' which in one copy in the British Museum are printed in red, in another in black. After the title-page comes a leaf containing a 'Table des Matieres; the verso being paged iv. The text occupies seventy-one numbered pages, ending with an erratum: 'P. 18, 1. 17, pour têtes lisex titres.' 'The last page is blank. An undated engraved edition, seemingly intended to be taken for a frcsimile of a draught in Frederick's own handwriting, is clearly later than this. 
We quote the passage as it stands in the Whittall version and put the variants in parentheses, calling those of the 1766 edition $A^{2}$, and the others $B$.

- Dans le temps du désordre et de la confusion (B les temps de desordre et de confusion) on vit tlever (B s'elever) au milieu des nations barbares, un commencement de souverainté nouvelle. Les Gouvernements (B Gouverneurs) de différens pays secouérent le joug, et bientôt devenus assez puissans pour se faire craindre par ( $\mathrm{B}$ de) leurs maîtres, ils obtinrent des priviléges, ou pour mieux dire, pour (B par) la forme d'un (B du) genou ( $A^{2} B$ genouil) à terre (B en terre) ils importerent ( $A^{\prime} B$ emporterent) le fonds ( $B$ fond). Dans le nombre de ces audacieux, il y en a plusieurs qui ont jetté le fondement (B les fondemens) des plus grandes monarchies, où $(B$ et) peut-ftre meme $(B$ à bien compter for meme) tous les Empereurs, Rois et Princes de nôtre temps (B Princes souverains) leur doivent leur états (sic; $A^{2}$ doivent leur état; $B$ doivent ils leurs états). Pour nous, nous sommes à coup sûr dans ce cas. Vous rougissez ( $A^{2}$ rougirez), allez, je vous pardonne ( $A^{\prime} B$ je vous le pardonne), mais ne vous avisez plus de faire l'enfant, et sachez pour toujours, qu'en fait de Royaume l'on prend quand on peût, et l'on n'a jamais tort que quand on est obligé de rendre. 'Reprenons, et que ceci soit dit en passant.'

The last sentence, 'Reprenons, et que ceci soit dit en passant' (which reads clumsily so near the beginning of the book), as also a foolish assertion in the next paragraph that there had been Neros among the Hohenzollerns, disappear in B, never to return. Moreover, excepting the corrections in the first line, as to which later editions fluctuate, all the improvements made in the B text held their place. It thus seems clear that the B text is the later, and it only remains for us to notice the few cases in which the 1766 edition $\left(A^{2}\right)$ differs from the Whittall text. The first of these is the spelling genouil for genou. As the modern form is genou, we are tempted to think that the Whittall reading is the III. 
later. But Littre informs us that when the spelling genouil held the field, the pronunciation was already genou. It is clear, therefore, that the author of the 'Matinées' wrote genou phonetically, and the printers corrected it to genouil, which suggests that the Whittall text is derived from a draught which printers had never touched, and the comparison of importtrent and emporterent in the next line points the same way. Again, leur etats in the Whittall text is clearly wrong, and that it appears as leur teat in $\mathrm{A}^{2}$ and as leurs etats in $\mathrm{B}$, seems to show that here again the Whittall text reproduces an original error which the printed editions corrected in two different ways. Two lines later, rougirez in $A^{8}$ may trouble us, but not for long, as it is corrected in the 'Errata' to rougissez. That $A^{2}$ agrees with $B$ in the improvement, je wous le pardonne for je vous pardonne, once more implies that the Whittall text is earlier, and we get a fresh and most striking confirmation of this in the fact that in line 4 the reading Gouvernements in which $A^{2}$ agrees with the Whittall text as against $B$, is altered in the errata to Gouverneurs, which is found in all subsequent editions.

We have thus discovered in the first place two distinct draughts, $A$ and $B$, and, secondly, two distinct stages of the earlier draught, with an editor who makes alterations as the book goes through the press. Two results seem to follow. The SavaryWhittall text, as representing an earlier stage of the first draught than any other printed text, must necessarily have been taken, as Savary asserted, from an original manuscript. Secondly, this manu- 
script must have been the King's; for ( 1 ) it is inconceivable that successively introduced variants of the nature of those we have set down should be the work of a forger; (2) as soon as we admit, as we now must, that Savary's text was really taken from a manuscript, it is impossible to dispute the truth of the rest of his story. Here then we have an edition of the 'Matinees' derived directly from a manuscript found on Frederick's writing-table. But on the assumption that they were compiled and circulated by the French Government, we should in the first place not expect to find the original manuscript in existence at all-it would naturally have been destroyed in order to conceal the fraud; or if it were in existence, the very last home where we should look for it, would be the palace of the libelled king himself:

Thus the Whittall family seem justified of the confidence they reposed in the French nobleman's story, and Frederick the Great may be regarded as the real author of these 'Matinées,' as they stand in the first edition of 1766 , or this new edition. It is necessary to make this qualification owing to the impossibility of deciding to what extent they were enlarged and corrupted in later editions by other hands. We may suggest, as at least a possible view, that the manuscript which Savary pocketed at Sans Souci was the very one brought to Paris by Buffon fils, and afterwards returned to the King, and that the numerous small improvements in what we have called the $B$ text were made in consequence of the French savant's friendly suggestions.

Lionel Glles. 